\title{
IMPLEMENTING PHILOSOPHY-BASED LANGUAGE TEACHING APPROACH TO IMPROVE STUDENTS' SPEAKING SKILL
}

\author{
Utary Rustam \\ utaryrstm@gmail.com \\ STAIN Parepare
}

\author{
Anwar \\ anwar@gmail.com \\ STAIN Parepare \\ Amzah \\ amzah@gmail.com \\ STAIN Parepare
}

\begin{abstract}
In university, in this case STAIN Parepare, the fourth semester students have been taught many kinds of speaking which varied based on different purposes. One of them is transactional speaking and Group Discussion is one of the kinds which frequently practised in college activity. In the initial study, it was found that students of the fourth semester in STAIN Parepare had low proficiency level in speaking and they had no motivation to participate in group discussion in speaking subjects. To overcome these problems, the writer implemented Philosophy-Based Language Teaching (PBLT) approach. This approach was selected to enhance students' thinking ability in group discussion in order that they build an idea then convey it to improve their speaking skill. This research was quantitative which employed pre-experimental research with one group pretest-posttest design. The data was collected by speaking test and observation then processed by statistical calculation by t-test nonindependent sample. Furthermore, the findings of this result revealed that PBLT approach is able to improve students speaking skill. Besides, this approach improved students' speaking skill through the existence of philosophical questions which allowed the discussion surrounded by active participation of group members. In addition, the findings indicated students' improvement in speaking skill both intellectual and social aspect. Finally, this research provided some suggestions to overcome some problems found during this research.
\end{abstract}

Keywords: PBLT approach, speaking skill, group discussion.

\section{A. INTRODUCTION}

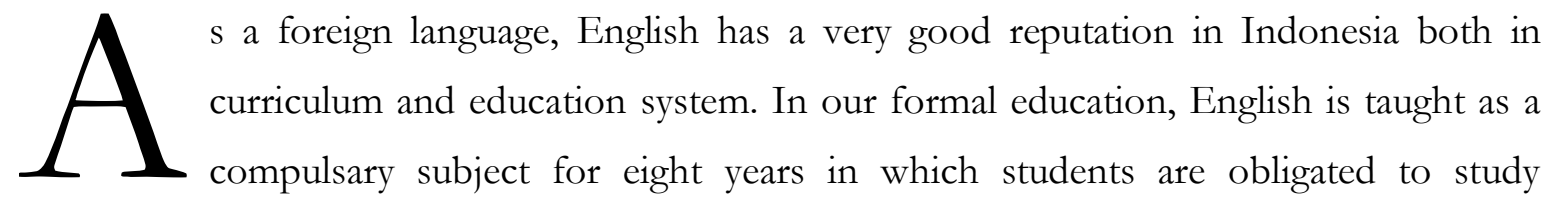

English. Learning English at school begins from elementary school until university level.

Although students have studied English for a long time, but their level of proficiency mostly are low, even for undergraduate students level. 
In University, speaking is the most preferred skills among other skills. This skills taught in the classroom for 4 semester with different kinds of speaking every semester, one of those kinds is Transactional Speaking with Group Discussion as the example. In the college activity, Group Discussion is frequently practiced in the classroom. This kind of speaking is a strategy to promote students' language productivity and creativity. Nevertheless, for undergraduate level, it is not only the ability to arrange words or utter sentences but also to construct concept within the mind. Moreover, undergraduates in their age tend to think critically than to accept all given information blindly.

Based on the researcher's experience as one of undergraduate student of STAIN Parepare, discussion in the classroom is often boring because lack of participation of the group members. They tend to be less interested and unmotivated to get involved in discussing conventional problems. Furthermore, when the topic they discussed is debateable, only some students who are active to give responses- the same students. these problems cannot only be perceived as the students' personal factors but also to the techniques of learning which take place in the classroom.

An effective discussion absolutely the goal of speaking class. To achieve this goal, learning process should be supported by proper and interesting approach, method, as well as techniques which are suitable with students' need in discussion process. Besides, this such learning process is expected to be able to improve students' speaking skill and thinking ability. In this case, one of the alternative offered approach that can be implemented is PhilosophyBased Language Teaching (PBLT) Approach.

PBLT approach is assumed able to assist students to construct concept and idea before speaking. Moreover, this approach is viewed suitable to undergraduate students who in their age not only add knowledge but also gain insight through thinking process. Idea which is constructed from their mind can help discussion activity become effective. This approach simply is an approach that use philosopical questions to improve students' productive skills and thinking ability.

In accordance with the background above, two research questions were drawn; 1) Is Philosophy-Based Language Teaching (PBLT) approach able to improve students' speaking skill at the fourth semester of STAIN Parepare? 2) How does Philosophy-Based Language Teaching (PBLT) approach improve students' speaking skill at the fourth semester of STAIN 
Volume 4, Number 01, June 2018

Parepare?. To complete her initial study, the researcher reviewed some studies related to the implementation of this approach.

\section{B. REVIEW OF THE LITERATURE}

Many studies report in the field of language teaching and learning show that in our English as a Foreign Language (EFL) class, students become excited to get involve in a group discussion when a philosopical question related to the topic is proposed. This report is supported by some research report such as by Joanna Haynes in 2002 and Van Der Leeuw in 2004. Furthermore, some related result by using this approach in the same and extended field will be presented as follows.

A study by Murris entitled "Teaching Philosophy with Picture Books" in 1992 reported that students who had engaged in philosophy-based discussion made more gains reading than those who had not. Another research result of Ofsted in the research in 1997 indicated that regular practice of philosophical inquiry led to significant gains in students overall use of their native language.

M.F. Daniel, L. La Fortune, R. Pallascio and M. Scheleifer in their study of Mathematics Education field entitled "Pbilosophical Reflection and Cooperative Practices in an Elementary School Mathematics Classroom" in 2011 the result showed that students in that class evolved both cognitively and in how they exchanged ideas from simple responses to a dynamic interventions of students in a dialogical context and involved higher-order thinking. Because we define philosophical dialogue in terms of questioning beliefs, deconstructing experience and prejudices, and searching collectively for meaning, they claimed that in the experimental class students philosophized more than in the control class (M.F. Daniel,, 1999).

Gholamhossein Shahini and A. Mehdi Riazi in their paper "A PBLT Approach to teaching ESL speaking, writing, and thinking skills" which conducted in one of the major universities in Iran. The result revealed that there was a significant difference between the two groups with students in the experimental group who were treated by using PBLT outperformed those in the control group on both speaking and writing tasks. Furthermore, the findings of the study have implications for all stakeholders in ELT locally and internationally(Gholamhossein Shahini and A. Mehdi Riazi, 2012) . 
The studies related to the implementation of this approach showed the good roles of PBLT Approach to improve students' thinking ability. In the field of English Language Learning, PBLT Approach is defined as a new approach in English teaching and learning in the classroom that engage students in discussions that surrounded by philosophical questions (Gholamhossein Shahini and A. Mehdi Riazip.174). The target of this approach are students' productive skills and thinking ability. In detail, the use of this philosophical questions is expected to stimulate students' thinking ability to build their idea and sincerely take part in a discussion either to express their idea and opinion or to support their friends' point of view. In addition, language in this approach is viewed as the tool for thinking. Vygotsky claims that thought and language at first are initiated separatedly, but then become interdependent during acts of communication, since meaning is established through interaction. In other words, the more idea, opinion or view are explored, the better speaking skill students can achieve.

Furthermore, It is essential that we should understand the term of philosophy in this approach clearly. In contrast to philosophy as a discipline, philosophy in this approach is not a complex, abstract or specialized philosophical discussion. The term of philosophy is a strategy to encourage students to discuss a question or set of questions deeply by discussing and reasoning their understanding about concepts or their ideas. Besides can open up into curiousity and sense of wonder, this approach provides social benefits in students' daily and school life.

To implement this approach into English teaching and learning process, some components should be introduced. At least, there are two main components of this approach according to Shahini and Riazi, they are community of inquiry and philosophical dialogues (Gholamhossein Shahini and A. Mehdi Riazip.174).

The first component is community of inquiry. In this approach, classroom is considered as a social community which work together to complete philosophical task. In this case, students cooperate to produce and then discuss their own questions about philosophical issues contained in the given text or another source.

These processes are expected to encourage students to have better responsibility towards their own learning process, and to develop themselves as independent learner. Besides, students can improve their intellectual courage when they express their own point of view in a group. In addition, Millet and Tapper argues that this community should help 


\section{Volume 4, Number 01, June 2018}

students to achieve rational questioning, intelligent agreement and disagreement among students. Stephan Millett \& Alan Tapper, 2011).

Lipman in Shahini and Riazi argues that there are some skills students can improve in such community, such as cognitive skills, making distinctions, seeing connections, identifying fallacies, finding analogies/disanalogies, seeing broader perspectives, formulating and testing criteria, sticking to the point, open mindedness, being willing to offer and accept criticism, valuing reasonableness, increasing tolerance against opposing ideas, drawing inferences. (Gholamhossein Shahini and A. Mehdi Riazi,, p. 172).

Hence, the researcher is of the opinion that in applying this community in the classroom context, group discussion is the most appropriate method to improve those skills among students. This opinion is considered based on Bahar's explanation that Participating in a group discussion will develop students' skills in using functional language and their cognitive and psychological abilities Andi Kaharuddin Bahar, 2014, p. 74).

Firstly, skill to use language functions. When students involve in a group discussion, they will require to use a variety of language functions that should be conveyed through some expressions. Students who use those expressions often, will be familiar, and familiarity will bring better mastery of the language use.

Secondly, they will have skill to analyze. As in a group discussion they will face some problematic issue or topic raised in their discussion, they will try to mind map the relevant opinion, idea, or view to draw the final conclusion or solution related to the topic or problem. It will promote their analysis skill and further their critical thinking ability. This point supportes the researcher's opinion to implement this approach in a group discussion.

Thirdly, the skill to persuade and convince. In a group discussion, students will find their friends have different opinion with them. To convince them, a student will try to support their opinion with examples or facts. When their friends agree and support their opinion, they have succesfully persuaded and convinced their friends. This condition will promote their skills in persuading and convincing.

The next skill is to respect others. In an effective group discussion, when mostly participants have the strong reason that support their different opinions, disagreement, interruptions and objections will occur. Different opinion and the followed situations will 
make the discussion become interesting. The diversity in the group then will make them learn to respect one another since each of them has the role to make their discussion attractive.

The last skill is to support one another. As explained in the previous paragraph, different opinions will be found in an attractive discussions. Diversity of them besides bring the skill to respect others, also find them to support one another since their different opinions will bring consideration to come in the best conclusion or solution to a problem or a topic.

The second component of this approach is Philosophical dialogues. According to Gregory, it does not need correct answer. These dialogues refer to a problem that cannot be solve by using calculation, definition in the book, or someone's experience, but the questions stimulate the kind of thinking which increases our understanding and lead us to ask the further questions.

It seems that, we need more consideration to know how the philosophical question is. Philip Cam in his book proposes the question quadrant. In this quadrant, questions are categorized as either open or closed and as either intellectual or based on the text. This distinguishes four kinds of questions that might be asked of any text: closed textual (reading comprehension) questions; open textual (literary speculation) questions; closed intellectual (factual knowledge) questions; and open intellectual (inquiry) questions. The first and third types are closed questions, those kind have had settled answers while, the second and fourth types are open and intellectual questions (Philip Cam, 2003, p.61-64). According to the explanation, it can be concluded that philosophical questions belong to the fourth quadrant.

These components in the classroom are very important to be brought in to a speaking class. To run a speaking class which implemented this approach, a framework by Lipman for second language teaching can be adopted, which contains three steps that initiated by presenting stimulus such as reading or multimedia text to create an issue, concept or openended situation. The next step is establishing students' cooperation to formulate specific question occured from the issue or concept. Finally, selecting the question for all group to be discussed, explored through dialog assisted by the facilitator. According to this framework, PBLT as an approach will be implemented in a group discussion within philosopical questions and answers will be proposed.

Some benefits of this approach are discussed in the study conducted by Millet and Tapper. This approach is thought as the practice of thinking together. There is built-in social 


\section{Volume 4, Number 01, June 2018}

dimension because participants are required to listen carefully and respond respectfully to the ideas of others. Therefore, it improves both cognitive and social aspect.

Moreover, this approach stimulates creative and critical thinking in students' minds. Because philosophy both encourages and relies upon those who can think for themselves. It involves a dimension of freedom which is defined as a capacity to take what one has learned and relate it to one's experience in new ways. Children who think for themselves are both critical thinkers and creative thinkers.

Besides extends students' thinking, this approach also encourages them to express that thought by speech. As a result, it can develop students' listening and speaking skill. This approach can also help students to develop not only cognitive and social but also emotional aspect. It enables them to be more patient with others and more able to reflect upon their own feelings and behavior.

Furthermore, this approach enables and encourages students to develop a personal value base by hearing different values and reasons which have been discussed. The reasons discussed ensure that the value they acquire are from deep thought and not simply adopted from book or experience (Stephan Millett \& Alan Tapper, 2011, p 6-8).

Regarding to the problems faced by the researcher especially students' of the fourth semester of English education study program of STAIN Parepare, and the theoretical foundation and framework of PBLT Approach, the researcher formulated 2 hypothesis; 1) Null Hypothesis $\left(\mathrm{H}_{0}\right)$ : implementing Philosophy-Based Language Teaching (PBLT) Approach is not able to improve students' speaking skill at the fourth semester of STAIN Parepare; 2) Alternative Hypothesis $\left(\mathrm{H}_{2}\right)$ : implementing Philosophy-Based Language Teaching (PBLT) Approach is able to improve students' speaking skill at the fourth semester of STAIN Parepare.

\section{RESEARCH METHOD}

This research was conducted in State Islamic College (STAIN) of Parepare that involved undergraduate students of the fourth semester. It took a month in its process including initial study, research activities as well as data analysis. 
Utary Rustam, Anwar, Amzah.Implementing Philosophy-Based...

This research was quantitative which employed pre-experimental research with one group pretest-posttest design. In this design, the effects of the treatment are investigated by analyzing the difference between the pretest and posttest scores. The comparison with a control group is not provided (John W. Best, 1977, P. 21).

In determining the population, researcher considered students who undergo the problem of speaking skill in discussion process. In STAIN Parepare, group discussions and debate are taken place at the fourth semester which are taught in Speaking 4 subjects. Therefore, the researcher decided to take the fourth semester students' of English Education Study Program (PBI) who attend the Speaking 4 subjects as the population of this research.

Based on the data, the number of students at the fourth semester of PBI in 2017 are 176 students. from those number of students, there are only 163 students who attend the Speaking 4 subjects which can be seen in the following table:

Table 1: Distribution of the Students of Speaking 4 Subjects

\begin{tabular}{|r|c|c|c|c|}
\hline \multirow{2}{*}{ No. } & \multirow{2}{*}{ Class } & \multicolumn{2}{|c|}{ Sex } & \multirow{2}{*}{$\begin{array}{l}\text { Number of } \\
\text { Students }\end{array}$} \\
\cline { 3 - 5 } & & Male & Female & 28 \\
\hline 1 & T 207 & 6 & 22 & 36 \\
\hline 3 & T 308 & 5 & 31 & 35 \\
\hline 4 & T 308 & 9 & 26 & 35 \\
\hline 5 & T 308 & 5 & 30 & 29 \\
\hline & Total 306 & 3 & 26 & $\mathbf{1 6 3}$ \\
\hline
\end{tabular}

(Source: Administration of ICT STAIN Parepare)

Since the number of population was big, the researcher chose some students as the sample by using purposive sampling technique. Consequently, the researcher chose twenty students from different classes who have active and passive role in group discussion in the classroom. In choosing the sample, the researcher consulted to the lecturer of Speaking 4 subjects.

To collect the data, The instruments used in this research were speaking test and observation. To gain data of students' speaking ability before and after treatment, students were tested by using speaking test which was applied in pretest and posttest. Pretest was conducted before the treatment to investigate students' prior speaking ability. Whereas, to 
Volume 4, Number 01, June 2018

measure students' speaking ability after the treatment (by implementing PBLT approach) posttest was conducted. Audio recorder was used in these activities.

While, Observation was used to investigate students' participation in discussion process which can reflect the way PBLT Approach improve students' speaking skill. The researcher believes that the more effective their discussion, the better their speaking will be. In this case, Green, Christopher and Lam in Richards recommend assigning one student each group to serve as an observer during the discussion activity using the observation form.

To analyze the data and test the hypothesis, researcher then processed it by using quantitative analysis with statistical method. The first is scoring students' test. The researcher assessed students' speaking test by using the oral proficiency scoring categories proposed by Brown. In this case, researcher integrated the criteria of grammar, vocabulary and pronunciation under the term of accuracy as illustrated in the following table with some adjustment for score:

Table 2: Teacher's Rating Scale for Speaking Test (H. Douglas Brown, 2004, P. 172)

\begin{tabular}{|c|c|c|}
\hline $\begin{array}{l}\text { Speaking } \\
\text { Component }\end{array}$ & Score & Criteria \\
\hline \multirow{5}{*}{ Accuracy } & 4 & $\begin{array}{l}\text { Grammar, vocabulary and pronunciation are equivalent to } \\
\text { and fully accepted by an educated native speaker. }\end{array}$ \\
\hline & 3 & $\begin{array}{l}\text { Able to use the language accurately on all levels normally } \\
\text { pertinent to professional needs. Errors in grammar and } \\
\text { pronunciation are quite rare. Can understand and } \\
\text { participate in any conversation within the range of his } \\
\text { experience with a high degree of precision of vocabulary }\end{array}$ \\
\hline & 2 & $\begin{array}{l}\text { Control of grammar is good. Able to speak the language } \\
\text { with sufficient structural accuracy and vocabulary to } \\
\text { participate effectively in most formal and informal } \\
\text { conversations on practical, social, and professional topics, } \\
\text { errors never interfere with understanding and rarely disturb } \\
\text { the native speaker. }\end{array}$ \\
\hline & 1 & $\begin{array}{l}\text { Can usually handle elementary constructions quite } \\
\text { accurately but does not have thorough or confident control } \\
\text { of the grammar. Has sufficient speaking vocabulary to } \\
\text { express himself simply, accent is intelligible though often } \\
\text { quite faulty. }\end{array}$ \\
\hline & 0 & $\begin{array}{l}\text { Errors in grammar and pronunciation are frequent, but } \\
\text { speaker can be understood by a native speaker used to } \\
\text { dealing with foreigners attempting to speak his language. }\end{array}$ \\
\hline
\end{tabular}


Utary Rustam, Anwar, Amzah.Implementing Philosophy-Based...

\begin{tabular}{|c|c|l|}
\hline & & $\begin{array}{l}\text { Speaking vocabulary inadequate to express anything but the } \\
\text { most elementary needs. }\end{array}$ \\
\hline Fluency & 2 & $\begin{array}{l}\text { Has complete fluency in the language such that his speech } \\
\text { is fully accepted by educated native speakers. } \\
\text { Able to use the language fluently on all levels normally } \\
\text { pertinent to professional needs. Can participate in any } \\
\text { conversation within the range of this experience with a high } \\
\text { degree of fluency. }\end{array}$ \\
2 & $\begin{array}{l}\text { Can discuss particular interests of competence with } \\
\text { reasonable ease. Rarely has to grope for words. }\end{array}$ \\
1 & $\begin{array}{l}\text { Can handle with confidence but not with facility most } \\
\text { social situations, including introductions and casual } \\
\text { conversation about current events, as well as work, family, } \\
\text { and autobiographical information. } \\
\text { No specific fluency description. }\end{array}$ \\
\hline 3 & $\begin{array}{l}\text { Comprehensability is equivalent to that of an educated } \\
\text { native speaker. } \\
\text { Can undestand any conversation within the range of his } \\
\text { experience. } \\
\text { Comprehen } \\
\text { sion }\end{array}$ & $\begin{array}{l}\text { Comprehension is quite complete at a normal rate of } \\
\text { speech. } \\
\text { Can get the gist of most conversations of non-technical } \\
\text { subjects (i.e., topics that require no specialized knowledge.) } \\
\text { Within the scope of his very limited language experience, } \\
\text { an understand simple questions and statements if delivered } \\
\text { with slowed speech, repetition or paraphrase. }\end{array}$ \\
\hline
\end{tabular}

Besides assessing students' speaking test, researcher also assessed students' discussion skill with PBLT Approach which was related to their speaking skill in the group discussion. It was listed in observation form proposed by Green, Christopher and Lam which can be seen as follows:

Table 3: Observation Form

\begin{tabular}{|c|l|c|c|c|c|}
\hline \multirow{2}{*}{$\mathbf{N}$} & \multicolumn{2}{|c|}{ Behavior } & \multicolumn{4}{|c|}{ Number of Contributions } \\
\cline { 3 - 6 } o & & A & B & C & D \\
\hline 1 & Total number of contributions made & & & & \\
\hline 2 & Responding supportively & & & & \\
\hline
\end{tabular}


Volume 4, Number 01, June 2018

\begin{tabular}{|c|l|l|l|l|l|}
\hline 3 & Responding aggressively & & & & \\
\hline 4 & Introducing new (relevant) point & & & & \\
\hline 5 & Digressing from the topic & & & & \\
\hline
\end{tabular}

Question no.1

Total number of participation:
$1-3=1$
$4-6=2$

more than $6=\mathbf{3}$

Question no.2 and 4

No $=1$

$$
\text { undecided }=\mathbf{2} \quad \text { yes }=\mathbf{3}
$$

Question no.3 and 5

Yes $=1$

undecided $=2$

no $=3$

Score Descriptions:

Poor: 1 - 5

rater

Fair: $6-10$

Good: 11- 15

\begin{tabular}{|c|c|c|c|}
\hline \multicolumn{2}{|l|}{ Group: } \\
\hline No & Students' Name & Total Score & Description \\
\hline 1 & & & \\
\hline 2 & & & \\
\hline 3 & & & \\
\hline 4 & & & \\
\hline
\end{tabular}

The second is classifying students' scores. The scores results were analyzed by using a scale system from a score range zero (0) to four (4). To provide qualitative description of the score range, a set of criteria was then adapted from Pedoman Akademik STAIN Parepare (Ahmad, S. Rustan, 2011, P.17). In the criteria, scores together with the score range as well as qualitative description were provided as shown in the table below:

Table 4: A Guideline for Evaluating Students' Speaking Skill

\begin{tabular}{|l|l|l} 
Scores & Score Ranges & Qualitative Descriptions \\
\hline
\end{tabular}


Utary Rustam, Anwar, Amzah.Implementing Philosophy-Based...

\begin{tabular}{|c|c|c|}
\hline 4 & $3,51-4,00$ & Very good \\
\hline 3 & $2,51-3,50$ & Good \\
\hline 2 & $1,51-2,50$ & Fair \\
\hline 1 & $0,51-1,50$ & Poor \\
\hline 0 & $0-0,5$ & Fail \\
\hline
\end{tabular}

The third is calculating mean score and standard deviation. In calculating the data, researcher operated Microsoft Excel computer program to present descriptive statistical information.

Finally, the last process is testing the hypothesis. To test the hypothesis, the researcher calculated the test of significance with 0.05 levels of significances with these criteria of testing hypothesis: 1) If t-test $<$ t-table, $\mathrm{H}_{0}$ is accepted and $\mathrm{H}_{\mathrm{a}}$ is rejected (implementing PBLT approach is not able to improve students' speaking skill); 2) If t-test $>\mathrm{t}$-table, $\mathrm{H}_{\mathrm{a}}$ is accepted and $\mathrm{H}_{0}$ is rejected (implementing PBLT approach is able to improve students' speaking skill).

\section{FINDINGS AND DISCUSSION}

\section{Findings}

The Pretest was conducted at the first meeting on the $3^{\text {rd }}$ of July 2017 started at $10 \mathrm{am}$. It was attended by twenty students. the result of pre-test showed average score of students' prior speaking skill before being taught by Philosophy-Based Language Teaching (PBLT) Approach was in the poor description with score 1,42. They mostly have low score in accuracy that they spoke ungrammatically with a very limited speaking vocabularies as well as in fluency since they spoke unnaturally with many pauses.

The posttest was conducted at the last meeting on the $14^{\text {th }}$ of July 2017 started at 9 am after giving the treatment by implementing Philosophy-Based Language Teaching (PBLT) approach for four meetings. This test was attended by twenty participants and ran by using the same test in the pretest. The result of students' speaking posttest showed the average score of students' speaking skill after being taught by Philosophy-Based Language Teaching (PBLT) Approach increased become 2,23 in posttest with fair description. The comparison of their scores can be seen in the following table.

Table 8 The Overall Result of Pretest and Posttest 
Volume 4, Number 01, June 2018

\begin{tabular}{|c|c|c|c|}
\hline \multirow{2}{*}{$\begin{array}{l}\text { Participant } \\
\text { Number }\end{array}$} & \multirow{2}{*}{ Participants' Initial } & \multicolumn{2}{|c|}{ Total Score } \\
\hline & & Pretest & Posttest \\
\hline 1 & $\mathrm{HK}$ & 2,0 & 2,7 \\
\hline 2 & MJ & 2,3 & 3,3 \\
\hline 3 & RS & 1,7 & 2,7 \\
\hline 4 & NW & 1,0 & 2,7 \\
\hline 5 & $\mathrm{FF}$ & 1,3 & 1,7 \\
\hline 6 & WA & 1,7 & 2,3 \\
\hline 7 & $\mathrm{MN}$ & 1,7 & 2,0 \\
\hline 8 & $\mathrm{HR}$ & 2,0 & 2,7 \\
\hline 9 & IS & 1,3 & 1,3 \\
\hline 10 & SS & 1,0 & 2,3 \\
\hline 11 & NA & 0,7 & 1,7 \\
\hline 12 & $\mathrm{TE}$ & 0,3 & 1,0 \\
\hline 13 & $\mathrm{RJ}$ & 1,0 & 2,3 \\
\hline 14 & MR & 0,7 & 1,7 \\
\hline 15 & $\mathrm{AA}$ & 0,7 & 1,3 \\
\hline 16 & $\mathrm{SM}$ & 3,0 & 3,3 \\
\hline 17 & NS & 0,7 & 1,3 \\
\hline 18 & MK & 2,3 & 3,3 \\
\hline 19 & $\mathrm{MU}$ & 2,3 & 3,3 \\
\hline \multirow[t]{5}{*}{20} & ND & 0,7 & 1,7 \\
\hline & Total & 28,3 & 44,7 \\
\hline & Mean & 1,42 & 2,23 \\
\hline & Standard Deviation & 0,72 & 0,74 \\
\hline & Description & Poor & Fair \\
\hline
\end{tabular}

(Source: Primary Data Processing)

The improvement of students' speaking skill was revealed by table 8 . As can be seen, students' gain scores between pretest and posttest mostly increased. Moreover, the increasing of the average score of students between pretest and posttest showed the improvement of their speaking ability from Poor to Fair classification.

Then, the data of pretest and posttest were used to test the hypothesis by using t-test nonidependent samples with the criteria if t-test $<\mathrm{t}_{\text {table }}=1,729(\alpha=0,05$ and $\mathrm{df}=19), \mathrm{H}_{0}$ is accepted. Meanwhile, if t-test $>\mathrm{t}_{\text {table }}, \mathrm{H}_{0}$ is rejected and $\mathrm{H}_{\mathrm{a}}$ is accepted. After calculating, Since t-test $=9,078>t_{\text {table }}=1,729$, so, $H_{0}$ was rejected and $H_{a}$ was accepted which meant 
implementing PBLT approach is able to improve students' speaking skill at the fourth semester of STAIN Parepare.

During the treatment process for four meetings, the researcher observed students' speaking ability when they studied in the classroom during discussion activity. The observation included their ability to practice the expressions of group discussion, ability to pronounce the expressions correctly as well as their number of contribution in conveying their idea. Besides, the observation also found that students' attitude in learning English improved. it included their enthusiasm in preparing the discussion material, motivation to take part in treatment activity which mostly was group discussion, as well as ability to appreciate their role in the group discussion.

From the observation form which investigated students' participation in group discussion that implementing PBLT approach showed that students participated more in the type of Problem-Based Group Discussion even though they spoke English with some intervention of mother tongue. Furthermore, they were more motivated to take part in the discussion, they appreciated their friends when they discussed they also tried their best to speak by using correct expressions. In short, from four treatments, students' quality in speaking skill was increased gradually.

\section{Discussion}

The first objective of this research is to find out the improvement of the result of speaking test which was applied in pretest and posttest. The results revealed that there was statistically significant improvement of students' gain score in speaking test after being taught by implementing PBLT approach.

The findings through observation showed that students had improvement especially in their attitude to study English in the classroom which led to the improvement of their speaking skill. For instance, students' skill to use language function improved as they are able to practice the expressions and pronounce them correctly in discussion process. Besides, they were more confident to speak in group discussion in persuading and convincing their friends to support their opinion. Also, students' skill of respect their friends can be seen from the way they listen to their friends carefully when each of them convey their idea in turn. In short, The Philosophy-Based Language Teaching (PBLT) approach which was implemented through group discussion was able to improve students' enthusiasm to express their opinion in group discussion. 


\section{Volume 4, Number 01, June 2018}

The researcher's initial study of students' at the fourth semester revealed that the process of group discussion was ineffective which make their speaking proficiency low before being taught by PBLT approach. This problem was then proved when the researcher conducted the pretest. According to their speaking test transcription in pretest, students who got poor classification prefer to be passive in the group discussion which use English as the tool of communication. They tend to be silent because of some factors; firstly, they had very limited vocabularies to discuss about the material in the classroom including some expressions that can be used to participate in the discussion, such as the expression of stating the opinion, aggreing, disagreeing as well as concluding the discussion. Secondly, they had no sense of responsibility in their group since they only counted on their friends who has the best English oral proficiency in their group. Finally, they had no repetition of practicing their English outside the classroom.

During the treatment for four meetings, the researcher initiated by building their friendship such as, get acquinted to the new friends, building their cooperation such as, completing a task in a game activity. Next, the researcher continued by giving them sixteen kinds of expression that they can use in the group discussion in order that they know what to say when they start a group discussion, state their opinion, state agreement and disagreement, interrupt politely, end the discussion, and another expressions. Then, the researcher gave them a handout with the explanation of leader and member's role in the group discussion in order that they realize their role in a group and not count on only to one friend to speak up.

Besides, the most influential material in the treatment process was philosophical question. This type of question made their discussion last longer than that by conventional question. As stated in chapter II that the dialogue of philosophical questions stimulate the kind of thinking which increases students' understanding and lead them to ask the further questions. The philosophical question played the important role also in the two type of discussion- problem-based and topic-based group discussion. For instance, when they discussed to solve the problem of the given situation in the third treatment and when they discussed the benefits of factory to their community in the fourth treatment. These kind of questions allow the discussion surrounded by the active participation of each member. Moreover, they keep discussing the problem until the end of the class. This condition force 
them to prepare the suitable vocabularies with the basic grammar to convey their sentences. Therefore, at the end of the class, the researcher always gave feedback not only based on their discussion result, but also their sentences related to grammar, proper vocabularies as well as the correct pronunciation. They also tried their best to practice the expressions of group discussion.

In this research after the treatment, posttest was conducted to investigate the effect of Philosophy-Based Language Teaching (PBLT) approach toward students' speaking skill. The result of posttest revealed that students' speaking skill was improved in all components. According to the transcription of their posttest, especially in fluency, students spoke with a normal rate of speech, good intonation and less unnatural pauses. As stated by Millet and Tapper that this approach encourages them to express that thought by speech. Eventually, it developed students' listening and speaking skills.

Furthermore, during the treatment, they were enthusiastic to prepare the material and the vocabularies they want to discuss in the classroom. Also, their understanding toward their roles encouraged them to take part actively in the group discussion and they did not count on their friends who has the best oral proficiency level in speaking anymore. As Millet and Tapper viewed that there is built-in social dimension because participants are required to listen carefully and respond respectfully to the ideas of other and to the role of others in the group discussion such as they respect to the role of the leader to manage discussion and the role of the participants to speak freely in stating their idea. Therefore this approach is thought as the practice of thinking together.

In addition, they were motivated to convey their idea and opinion eventhough sometimes their speech was combined with Indonesian and affected by mother tongue. Through the observation, the researcher saw that students appreciated all the process of reasoning together with their friends in their group because the reasons which they discussed ensure that the value they acquired were from deep thought and not simply adopted from book or experience. By hearing different values and reasons which have been discussed, students' personal value base was developed.

Finally, they keep discussing the material until the end of the class which led them to practice the expressions of group discussion and it enabled them to be more patient with others and more able to reflect their own feelings and behavior. As stated by Millet and 


\section{Volume 4, Number 01, June 2018}

Tapper that this approach can help students to develop not only their cognitive and social aspects but also students' emotional aspects.

Besides their speaking skill, this approach enhanced students' critical thinking which can be seen during the discussion process when they answered and commented their friends' questions and opinion. Millet and Tapper are of the opinion that philosophy involves the dimension of freedom which is defined as capacity to take what a student has learned and relate it to the other student's experience in new ways. Therefore, this approach stimulates students' thinking ability.

In short, these findings indicated students' improvement in speaking skill both intellectual and social aspect after being taught by PBLT approach. Besides, it developed students' emotional aspect to be more patient towards others, respect each other as well as support one another. By Bahar in his book, respecting each other and supporting one another are the subskills that can be develop through participating in group discussion. Therefore, Philosophy-Based Language Teaching (PBLT) approach was suitable to be implemented in group discussion because they supported one another to improve students' speaking skill and enhance students' social subskills.

\section{E. CONCLUSION AND SUGGESTION}

\section{Conclusion}

Based on the findings and discussion of this research, it can be concluded that Philosophy-Based Language Teaching (PBLT) Approach is able to improve students' speaking skill. The result of testing hypothesis through t-test calculation showed that t-test calculation 9,078 is greater than t-table 1,729 which means $\mathrm{H}_{0}$ was rejected and $\mathrm{Ha}$ was accepted. Furthermore, this improvement can be seen in the result of pretest and posttest. The data analysis in pretest and posttes showed that students' gain score increased from 1,42 in pretest become 2,23 in posttest which indicated their speking skill from Poor to Fair classification.

In addition, the findings of the observation showed that this approach improves students' speaking skill through the existence of philosophical questions which were combined by some techniques such as jig saw technique and the material which was 
distributed through handouts. These approach was implemented in the classroom in the group discussion form. It allowed the group discussion surronded by the active participation of the group members. Finally, this findings indicated students' improvement in speaking skill both intellectual and social aspect after being taught by PBLT approach.

\section{Suggestion}

Although the findings showed that this approach is able to improve students' speaking skill in group discussion, but there are some suggestion should be considered by the teacher, the students, and the next researcher as weel.

For the teacher, as the facilitator, teacher should assisst students to create the proper dialog which can build their idea before uttering a sentence. To add their knowledge, teacher can visit the website www.askphilosophers.com. Besides, teacher should help students to deepen their understanding by asking for clarification after answering or giving opinion. In preparing the material, text is not the main material for philosophical dialogues. Text is just meant to motivate students to talk. Finally, teacher should supervise the discussion in order that students' will not digress from the main topic of discussion.

For the students, when they participate in the group discussion, they should prepare the given topic in order that they have complete material to be discussed with their friends, because preparation seems to be the major problem of students when they want to discuss in the classroom.

For the next researcher, this approach still needs to investigate more about students' critical thinking. Although the researcher did not use specific measures for students' attitudes and motivation toward PBLT approach and she did not measure their development in thinking and reasoning skills, but her observations of students' participation, feedback and reflections in the group discussion become the proof of such potentialities.

\section{REFERENCES}

Abubakar, M. S. (2015). Improving the Second Year Students' Speaking Ability through Project Based Learning (PBL) at MTsN Model Makassar. ETERNAL (English, Teaching, Learning, and Research Journal), 1(2), 216-228.

Asik, N., \& others. (2016). The Effectiveness Of Using Visual Aids Integrated Communicative Language Teaching Method In Improving The Students'speaking Ability At The Second Grade Of Sman 1 Pinrang. ETERNAL (English, Teaching, Learning, and Research Journal), 2(2), 167-182. 
Bahar, A.Kaharuddin. 2014. Transactional Speaking: A Guide to Improve Transactional Exchange Skills in English for Group Discussions (GD) and Interviews. Samata Gowa: Gunadarma Ilmu.

Best, John W. Research in Education. 1977.New Jersey: Prentice Hill.

Brown, H. Douglas. 2004. Language Assessment: Principles and Classroom Practices. New York: Pearson Education INC.

Cam, Philip. 2017 “The Question Quadrant”, Critical and Creative Thinking, vol.11 no.2 (2003).

Daniel, M.F. et al. 2017. Philosophical Reflection and Cooperative Practices in an Elementary School Mathematics Classroom, Canadian Journal of Education, vol. 24 no. 4 (1999), p. 436. http://journals.sfu.ca/cje/index.php/cje-rce/article/view/2767 (April 28).

Millett, Stephan \& Alan Tapper. 2017. "Benefits of Collaborative Philosophical Inquiry in Schools", Educational Philosophy and Theory, (2011). http://onlinelibrary.wiley.com/doi/10.1111/j.1469-5812.2010.00727.x (accessed April 28).

Mehdi Riazi. 2017. " A PBLT Approach To Teaching ESL Speaking, Writing, And Thinking Skills," ELT Journal , Vol. 65 no.2. (January 2012). https://www.researchgate.net/publication/235982562_A_PBLT_approach_to_teachi ng_ESL_speaking_writing_and_thinking_skills ( accessed April 28).

Nasir, S. H. (2015). To Improve Students'interpersonal Communication Skills By Means Of Cooperative Learning Ioc At Piba Program Of Uin Alauddin Makassar. ETERNAL (English, Teaching, Learning, and Research Journal), 1(1), 84-97.

Rustan, Ahmad S. Et al. 2011. Pedoman Akademik STAIN Parepare 2010-2011. Parepare: STAIN Parepare.

Rahmah, F., \& St Nurjannah, Y. T. (2016). The Use Of Scaffolding Talk Technique To Improve The Second Grade Students Speaking Skill At Mts Madani Paopao Gowa. ETERNAL (English, Teaching, Learning, and Research Journal), 2(2), 252-268.

Rahman, I. F., \& others. (2017). Implementing Picture Dictation In Improving Speaking Ability Of The Second Year Students At Ma Pesantren Guppi Samata. ETERNAL (English, Teaching, Learning, and Research Journal), 3(2), 190-205.

Rusdi, S. Y. F. (2015). Improving the Students Speaking Ability by Using Thematic Materials (a Classroom Action Research to the First Year Students of MTSN. Model Makassar). ETERNAL (English, Teaching, Learning, and Research Journal), 1(2), 257-269. 